2. Картава Ю., Косаєва Н.; Дитина 3 порушеннями зору в умовах інклюзивної освіти: метод. посіб. - Суми : Видавництво СумДПУ ім. А.С. Макаренка, 2010. - 80 с, С. 25-26.

3. William B. Robinson. Simulation, not simulation: an alternate approach to history teaching games. The history teacher. Vol. 46. Number 4. August 2013. P. 578.

4. Туминская О.А. Урок в музее и музейный урок. Известия РГПУ имени А.И. Герцена. 2020. № 195. С. 104.

5. Candlin, F. (2006). The dubious inheritance of touch: Art history and museum access. Journal of Visual Culture, 5(2), 137-154.

6. Збереження музейного фонду України: сайт: URL: https://protocol.ua/ua/pro_muzei_ta_muzeynu_spravu_stattya_21/ (дата звернення: 20.09.2020.

DOI https://doi.org/10.30525/978-9934-588-80-8-2.44

\title{
ІНТЕРАКТИВНІ МЕТОДИ НАВЧАННЯ ІСТОРІЇ
}

\author{
Рапасва М. B. \\ кандидат педагогічних наук, \\ дочент кафедри суспільних наук, викладач \\ Київський коледж легкої промисловості \\ м. Київ, Украӥна
}

Метою роботи $є$ розгляд питань, пов'язаних 3 поняттям сучасних інтерактивних методів навчання студентів, а також продемонстрована їх практична реалізація на прикладі навчальної дисципліни «Історія: Україна і світ».

Зростання ролі знань $є$ пріоритетом розвитку постіндустріального суспільства, тому освіта все більше позиціонується міжнародною спільнотою як дієвий інструмент формування особистості, здатної бути конкурентоспроможною. Це зумовлює необхідність оновлення i удосконалення всіх ланок освіти, іiі змісту і навчальних технологій, що вимагають нові запити інформаційного суспільства.

Система вищої освіти України, адаптуючись до вимог Болонського процесу та суспільних трансформацій, зумовлених глобалізаційними процесами, вимагає нових підходів і принципів до формування компетенцій викладачів, методів їх взаємодії зі студентами. 3 метою модернізації системи освіти в Україні розробляється і оновлюється відповідна законодавча і нормативна база, визначаються нові стратегії 
iii розвитку. Національна стратегія розвитку освіти в Україні на 2012 2021 роки визначає необхідність кардинальних змін, спрямованих на підвищення якості i конкурентоспроможності освіти в нових економічних і соціокультурних умовах, інтеграцію її в європейський i світовий освітній простір. 3 огляду на визначені пріоритети найважливішим для держави $є$ виховання людини інноваційного типу мислення та культури, забезпечення особистісного розвитку людини згідно з ії індивідуальними задатками, здібностями, потребами на основі навчання протягом життя.

Відповідний документ зазначає нагальну необхідність підтримки наукової та інноваційної діяльності за допомогою педагогічних технологій, пов'язаних 3 діалогізацією процесу навчання і гармонійним розвитком як тих, хто навчає, так і тих, хто навчається [1, с. 2-35]. Такі задачі вимагають від викладача не лише вміння передавати знання студентам, а й переходу до принципово нової демократичної взаємодії 3 ними на засадах відносин партнерства, поваги, довіри. Звичайно, за таких умов функції викладача трансформуватимуться з транслятора інформації на «навігатора» в ній. Викладач в цьому випадку постає як організатор і фасилітатор (від англ. Facilitator) - той, хто полегшує діяльність, забезпечуючи оптимальні умови для самореалізації особистості студента. Викладач має сприяти поштовху студентів до саморозвитку, що вирішується шляхом впровадження інноваційних технологій, де важливе місце посідає саме інтерактивне навчання. За таких умов використання інтерактивних методів роботи для студентів $є$ актуальним на сьогодення.

Дослідження різних рівнів доводять, що за умов пасивного навчання засвоюється $10 \%$ інформації, за умов активного навчання (ділових ігор, дискусій) - 50\%, а за умов інтерактивного навчання (взаємонавчання i негайного застосування знань один до одного) - 90\% [2, с. 8].

Відповідно до критерію характеру взаємодії викладача і студентів методи навчання розподіляються на пасивні, активні та інтерактивні [3, с. 109]. За умов використання інтерактивних методів навчання на заняттях 3 історії студенти працюють групами, командами, а викладач має не передавати знання студентам, а спрямовувати їх роботу за допомогою завдань як інструментарію. Це полегшує діяльність, забезпечує оптимальні умови для самореалізації студентів, сприяє зростанню самооцінки особистості.

Психологічні дослідження доводять, що виконувати завдання група може тільки за умов взаємодопомоги учасників для досягнення спільного успіху, що зумовлює більш сильних учасників стимулювати слабких. Таке стимулювання створює стосунки позитивної взаємозалежності. Це призводить до формування навичок соціальної поведінки, в основі якої закладаються технології сумісної роботи, де швидко приймаються оптимальні конструктивні рішення, формується 
вміння брати на себе відповідальність, навчатися спілкуватись, вирішуючи конфліктні ситуації. Знання, уміння і навички 3 історії поєднуються з активною життєвою позицією.

Обсяги нашого дослідження не дозволяють повною мірою висвітлити весь інструментарій інтерактивних методів навчання історії, тому спробуємо наочно показати деякі з них на прикладі авторської розробки за темою: «Перехід від індустріального до постіндустріального суспільства. Глобальні соціальні зміни». Заняття проводиться за допомогою інтерактивних методів навчання. Студенти працюють за таким планом: 1. Загальна характеристика глобалізаційних процесів сучасності. 2. Суспільство виробництва і суспільство послуг. Теорія макдональдизації Д.Рітцера. 3. Американізація як продукт масової культури постіндустріального суспільства.

За цим планом студенти заздалегідь, використовуючи рекомендовану викладачем літературу, ознайомлюються 3 питанням 3 метою знайти $\mathrm{i}$ систематизувати для себе якомога більшу кількість інформації. Хід i структура заняття за темою здійснюється наступним чином.

Перше питання плану опрацьовується за допомогою мозкового штурму. Студенти розподіляються на дві групи, які протягом певного часу спільними зусиллями виробляють якомога більше ідей, збирають найбільшу кількість інформації на поставлені запитання за напрямами: позитивні і негативні наслідки глобалізації в економічній, політичній, соціальній, релігійній та культурній сферах. Перша команда має виділити максимальну кількість позитивних наслідків в усіх сферах, друга - негативних. Кожна команда фіксує письмово визначені нею позитивні та негативні характеристики. Далі між групами починається змагання, де кожна команда за чергою наводить свої аргументи. Групою - переможцем буде вважатись та, яка запропонувала найбільшу кількість наслідків глобалізаційних процесів сучасності.

Друге питання плану опрацьовується наступним чином. Група студентів розподіляється на команди 3 двох осіб, де один студент має знайти і надати позитивні риси макдональдизації, другий - негативні. По завершенні часу на підготовку кожна 3 невеличких команд презентує результати своєї роботи. Таким чином, більш глибоко і динамічно розглядається і засвоюється суперечлива проблема, а студенти в дебатах навчаються підтверджувати свою точку зору шляхом аргументації на захист своєї позиції, формують вміння дискутувати цивілізовано.

Третє питання заняття вирішується студентами шляхом дискусії у вигляді ток-шоу. Для цього створюється група експертів, решта студентів - учасники і глядачі шоу. Роль ведучого бере на себе викладач як фасилітатор у взаємодії студентів - учасників шоу. Кожен з експертів захищає своє бачення позитивних і негативних впливів американської масової культури на світовий простір. Глядачі ставлять експертам свої 
запитання, дають своє баченням певних аргументів, можуть робити свої повідомлення, експерти відповідають. Експерти також можуть дискутувати між собою протягом обговорення питань.

Висновки щодо проведення роботи за темою кожен зі студентів стисло робить у письмовій формі на окремому аркуші шляхом відповідей на такі незакінчені речення, заздалегідь сформовані викладачем: 1. «В опрацюванні цієї теми важливим для мене було...», 2. «Я навчився...», 3. «Надалі я хотів би навчитися...». Письмові відповіді на ці питання викладач аналізує для подальшого вдосконалення інтерактивних методів навчання у своїй професійній діяльності.

Таким чином, інтерактивна взаємодія - співнавчання (колективне, групове, навчання у парах) надає можливість сформувати у студентів велику кількість вмінь і навичок, корисних для практичної реалізації своїх здібностей у сучасному суспільстві. Такими навичками $є$ уміння формувати свої думки в усній та письмовій формі; володіння технікою публічних виступів; здатність працювати не тільки в команді, а i самостійно; вміння планувати, проектувати та продуктивно розподіляти час (ефективний тайм-менеджмент), швидко адаптуватись до нових ситуацій; розвивати креативні здібності тощо.

За допомогою демонстрації авторської розробки заняття 3 історії нами було продемонстровано деякі методи роботи студентів, зокрема методи створення позитивної атмосфери навчання i організації комунікації студентів, актуалізації знань, засвоєння нових знань, формування вмінь, навичок, узагальнення і систематизації знань як складових інтерактивного навчання.

\section{Література:}

1. Національна стратегія розвитку освіти в Україні на 2012-2021 роки http://www.mon.gov.ua/images/files/news/12/05/4455.pdf

2. Пометун О., Пироженко Л. Інтерактивні технології навчання: теорія, практика, досвід: метод. посіб. авт.-уклад. О.Пометун, Л. Пироженко. - К.: А.П.Н.; 2002. - 136 с.

3. Пометун O.I. Енциклопедія інтерактивного навчання. - К. : 2007. -144 c.

4. Пометун О. Методика навчання історії в школі / О.І. Пометун, Г.А. Фрейман. - К.: Генеза, 2006. - 382 с.

5. Социально-экономические проблемы информационного общества: монография / под ред. д.э.н., проф. Л.Г. Мельника, к.э.н., доц. М.В. Брюханова. - Вып. 2. - Сумы: Университетская книга, 2010. - 896 с. 